Research Article

\title{
Performance of Geosynthetic-Reinforced and Cement-Fly Ash-Gravel Pile-Supported Embankments over Completely Decomposed Granite Soil: A Case Study
}

\author{
Lijun Wu \\ College of Environment and Civil Engineering, Chengdu University of Technology, Chengdu 610031, China \\ Correspondence should be addressed to Lijun Wu; wulijun2012@cdut.cn
}

Received 28 August 2017; Revised 6 November 2017; Accepted 21 November 2017; Published 14 February 2018

Academic Editor: Fernando Lusquiños

Copyright (c) 2018 Lijun Wu. This is an open access article distributed under the Creative Commons Attribution License, which permits unrestricted use, distribution, and reproduction in any medium, provided the original work is properly cited.

\begin{abstract}
This paper presents a full-scale test of the high-speed railway embankment to investigate the performance of cement-fly ash-gravel (CFG) pile-supported embankments over completely decomposed granite (CDG) soils. The authors compared the embankments built on CDG soils reinforced by geogrid only and geogrid and CFG piles in terms of ground settlement, layer settlement, and pile efficacy. Experimental results show that the CFG pile-supported embankment built on CDG soils performs well. The soil arching of CFG piled reinforcement is effective and significantly increases with surrounding soil consolidation. Furthermore, the increase in the soil arching effect is heavily dependent on differential settlements between surrounding soils and piles. Five methods widely adopted in current designing were used to calculate the pile efficacy. The prediction for pile efficacy by the Nordic method, BS8006, and its modified version is significantly higher than measured values. By contrast, the calculation by the EBGEO and CA model method is more approximate to the measured results in both the pattern and the value at the end of construction. Therefore, the adaptability of the EBGEO and CA model method outperformed that of the Nordic method, BS8006, and its modified version. Finally, in this case, the CA model method was recommended to estimate the pile efficacy of CFG pile-supported embankments built on CDG soils.
\end{abstract}

\section{Introduction}

Over the past two decades, many high-speed railways have been constructed in China. In order to ensure that those high-speed railways can normally operate in design life, pilesupported embankments (GRPS) are widely adopted to reduce large differential settlement and postsettlement, for example, cement-fly ash-gravel (CFG) pile-supported embankments built over soft soil ground [1-4] and cementmixing $(\mathrm{CM})$ pile-supported embankments built over soils of medium compressibility [5]. Chinese code for high-speed railway designs [6] requires a postsettlement less than $10 \mathrm{~cm}$ and a differential settlement less than $5 \mathrm{~mm}$ for an operation speed of $250 \mathrm{~km} / \mathrm{hrs}$.

Recently, some regional high-speed railways have been built on completely decomposed granite (CDG) soils which arise from the granites. In many cases, completely decomposed granite soils show a high shear strength and stiffness.
However, in practical infrastructure projects, engineers often encounter a significant change of CDG soils in the shear strength when they are subjected to wetting [7-9]. It consequently results in an excessive deformation and even a failure of the overlying infrastructure. The important change in the physical and mechanical properties of CDG soils heavily depends on the mineralogy composition and weathering degree. In previous researches, to avert the aggravation of pile penetration during embankment filling, end-bearing piles such as CFG piles were not recommended to reinforce the soils with low shear strength.

Previous researches focus on the physical and mechanical characteristics of CDG soils using laboratory tests. Some researchers performed a series of large-scale experiments regarding GRPS embankments built over CDG soils $[10,11]$. Oh and Shin [12] reported a full-scale experiment for GRPS embankments built on the mixture of soft soil and weathered granite with high compressibility. Shahu and 
Reddy [13] analyzed the long-term mechanism of load transfer using the results of full experiments for the floating stone column. More recently, van Eekelen [14] validated concentric arches (CA) models with large- and full-scale experiment results. It seems that the CA model method can perform well in reinforcing low-medium embankments $(H \leq 5 \mathrm{~m})$ built on soils of low strength. Until now, there has still been lack of full-scale experimental results for CFG pilesupported embankments built on CDG soils of medium compressibility. Consequently, the performance of CFG pile-supported embankments built over CDG soils has not been evidenced by field data.

In this case, CFG piles combined with geogrid were adopted as an improvement method to reinforce the embankment built over CDG soils, while an unreinforced section was presented as a reference case. Depending on the mechanical properties obtained from laboratory tests, a trial experiment was conducted to monitor the ground surface settlements, the layer settlements, and the stresses on surrounding soils and pile heads in nearly three years. The field data were analyzed in order to study the load transfer mechanism of the CFG pile-supported embankment as well as the effect of surrounding soil support and pile parameters on its development. Upon discussion, pile efficacy was used to assess the efficiency of the soil arching effect for GRPS embankments. Finally, in order to optimize current designing methods, five approaches were adopted to calculate the pile efficacy for comparison.

\section{Full-Scale Test Embankment of HESR}

2.1. Site Conditions and Soil Profiles. A full-scale test embankment was constructed along the Hainan Eastern Ring High-Speed Railway (HESR) with an operational speed of $250 \mathrm{~km} / \mathrm{h}$. One section of the embankment (referred to as G1) is of the geogrid-reinforced and CFG pile-supported embankment, while another (referred to as G2) is only of geogrid reinforced as a reference case for comparison. The embankment ground mainly consists of the completely decomposed granite soil layer with thicknesses varying between $20 \mathrm{~m}$ and $30 \mathrm{~m}$, which is underlain by a granite layer with medium-to-high degrees of decomposition. Note that a thin layer of soft clay of about $0.5 \mathrm{~m}$ in thickness was also identified at shallow depths in the embankment sections. The water table is at a depth of about $0.5 \mathrm{~m}$, implying that most of the soils are fully saturated. Figure 1 displays the longitudinal view of the test embankment and its corresponding soil profiles.

A series of laboratory tests were carried out on "undisturbed" soil samples retrieved from the test embankment site to characterize the CDG soil profiles. Those tests include traditional tests to determine basic physical properties, oedometer tests, and consolidated-drained triaxial compression tests. All the undisturbed soil samples were retrieved from the test site at five different depths $(2 \mathrm{~m}, 4 \mathrm{~m}$, $8 \mathrm{~m}, 10 \mathrm{~m}$, and $14 \mathrm{~m}$ ) by using the tube sampling method as per the Chinese Technical Specification JGJ/T87-2012 [15] prior to embankment construction. Figure 2 presents the CDG soil profiles of the test site. We can observe that the

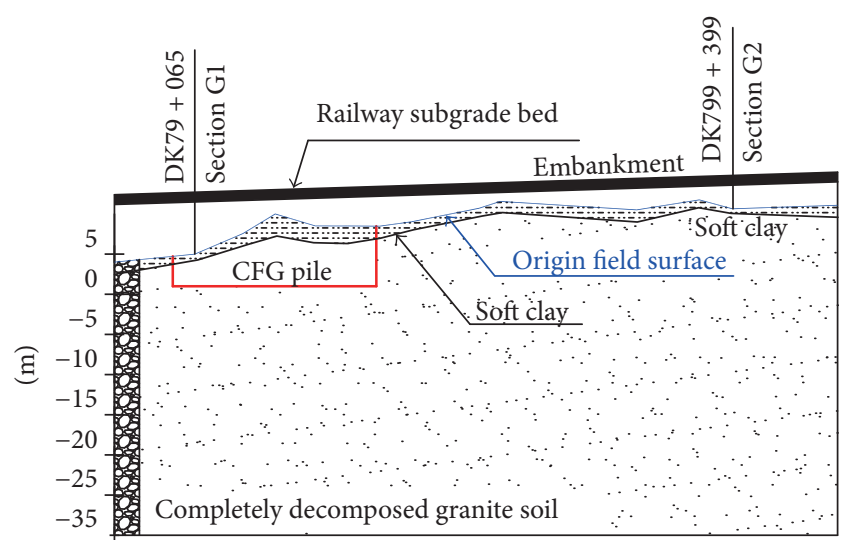

Figure 1: Schematic longitudinal view of the test embankment.

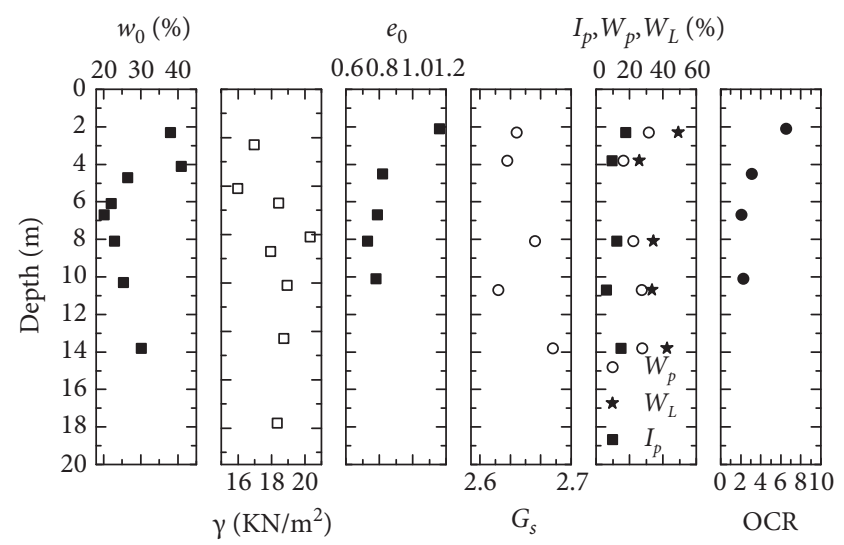

FIgURE 2: Soil profiles of the test site at HEHR: $w_{0}$, natural water content; $\gamma$, unit weight; $G_{s}$, specific gravity; $W_{p}$, plastic limit; $W_{L}$, liquid limit; $I_{p}$, plastic index; $e_{0}$, initial void ratio; OCR, overconsolidation ratio.

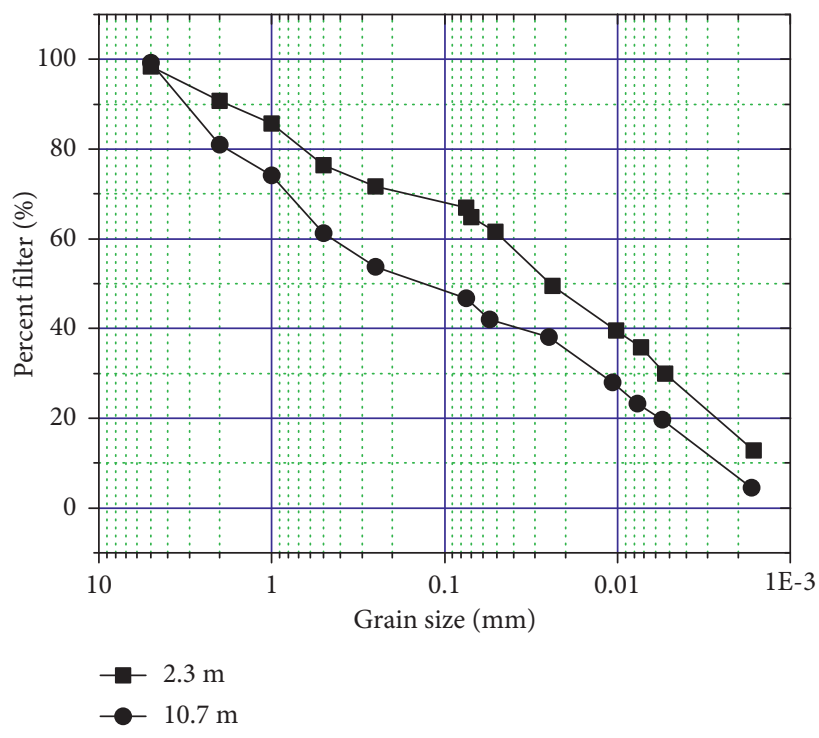

Figure 3: Particle size distribution curves of CDG soils at depths of $2.3 \mathrm{~m}$ and $10.7 \mathrm{~m}$, respectively. 


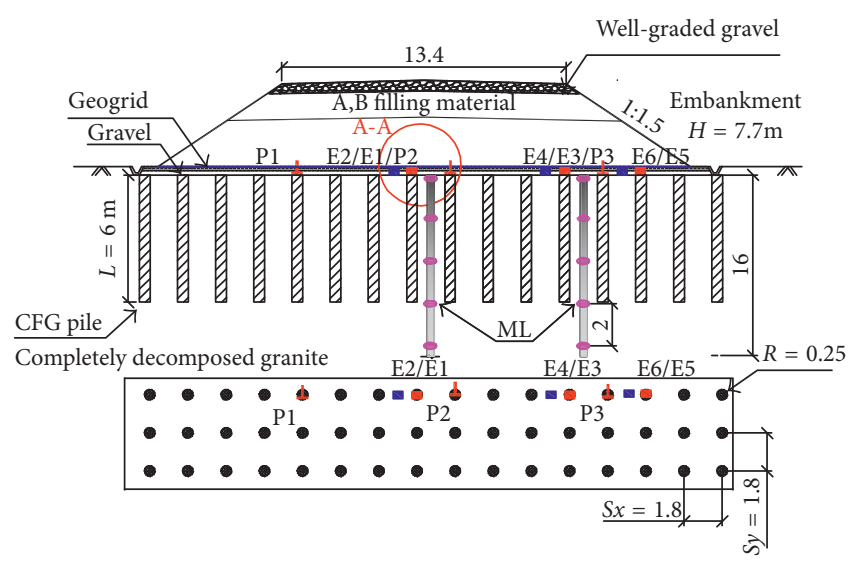

(a)

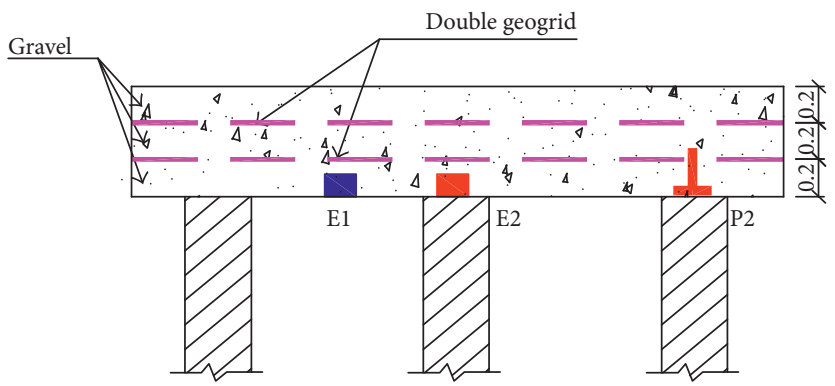

(c)

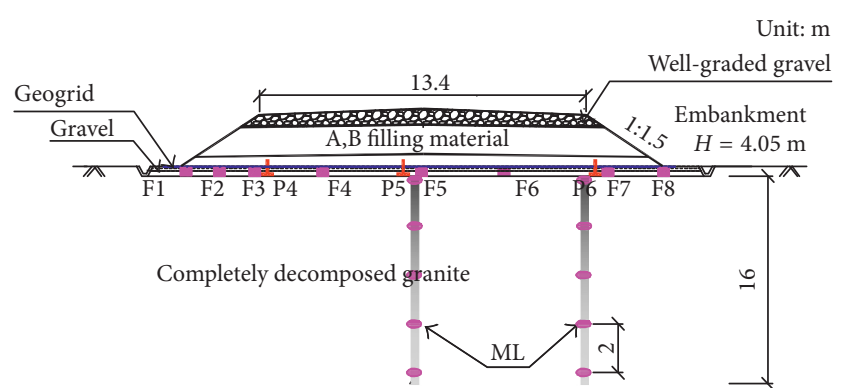

(b)

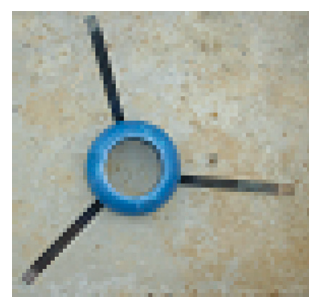

(d)

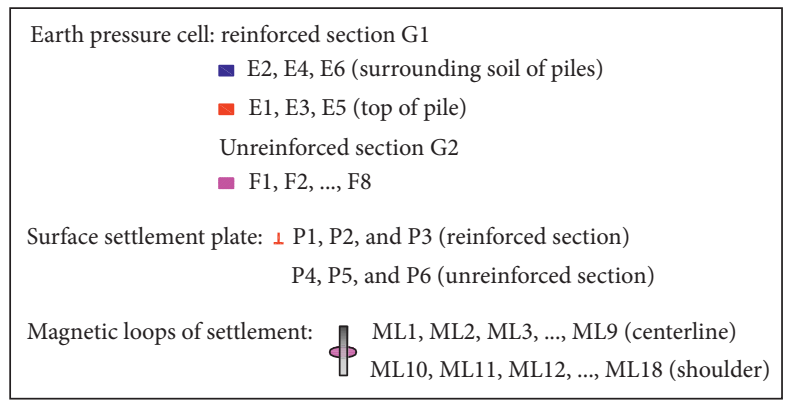

FIGURE 4: Cross section of instrumented test embankment sections. (a) Reinforced section G1. (b) Unreinforced section G2. (c) Geogridreinforced gravel cushion (A-A).

CDG soils have a medium-to-high plasticity characterized by a plasticity index of 6.06-17.1. They are heavily overconsolidated in the upper soil layer with a maximum OCR of up to 6.54 at a depth of $2 \mathrm{~m}$, whereas they are lightly overconsolidated in the layers below $8.0 \mathrm{~m}$ in depth. Based on soil particle size distribution (PSD) curves presented in Figure 3 and the Atterberg limits, the CDG soils can be classified as coarse-grained soils and sand-clay mixtures [16].

2.2. Embankment Construction and Field Instrumentation. Two embankment sections (herein G1 and G2 are referred to as reinforced and unreinforced embankments) were fully instrumented, and their cross section view was presented in Figure 4. The sections G1 and G2 have a height of $7.7 \mathrm{~m}$ and $4.05 \mathrm{~m}$, respectively. Their crest width is $13.4 \mathrm{~m}$, and their side of slope is $1 \mathrm{~V}: 1.5 \mathrm{H}$ (V: vertical, $\mathrm{H}$ : horizontal). The fill material is made of some local cohesive soils treated with cement of about $6 \%$ in mass. The CFG piles in section G1 are cylindrical with a diameter of $0.5 \mathrm{~m}$ and configured in square with a center-to-center spacing of $1.8 \mathrm{~m}$. The geogrid layer in both sections consists of double geogrids with a tensile strength of $80 \mathrm{kN} / \mathrm{m}$ in both longitudinal and transversal directions, which sandwiches a well-graded gravel layer of $0.6 \mathrm{~m}$ in thickness. From the top to the bottom, the geogrid reinforced layer is composed of a gravel layer with a thickness of $0.2 \mathrm{~m}$, a bidirectional geogrid, a gravel layer with a thickness of $0.2 \mathrm{~m}$, and a bidirectional geogrid, a gravel layer with a thickness of $0.2 \mathrm{~m}$, as illustrated in Figure 4 .

Figure 3 shows all the types and locations of sensors for test embankment monitoring. All sensors were installed prior to embankment construction and/or after construction of the piles for section G1. The detailed instrumentation includes the following: (i) three surface settlement plates $(\mathrm{P} 1, \mathrm{P} 2$, and P3) with a geometrical size of $50 \mathrm{~mm} \times 50 \mathrm{~mm} \times$ $1 \mathrm{~cm}$ (thickness) were installed on the top of piles near the embankment centerline and vertical lines through the left and right shoulder. Those surface settlement plates are just 
below the geogrid layers at the center of the square configuration of pile caps in section G1, and the same configuration is applied to section G2. (ii) Magnetic loops (referred to as ML1-ML18) with an accuracy of $0.5 \mathrm{~mm}$ were positioned beneath the centerline of the embankment with the vertical spacing of $2 \mathrm{~m}$ for probing the differential settlements of soil sublayers in both test sections. All nine magnetic loops were installed along the length of an access pipe which was positioned in a borehole drilled prior to the embankment construction. (iii) Earth pressure cells (referred to as F1-F8) with a diameter of $120 \mathrm{~mm}$ and a measuring range of $0-2 \mathrm{MPa}$ were installed below the geogrid-reinforced cushion to measure the stress distribution in unreinforced section G2. The instrumentations were positioned at different places (centerline, shoulder, toe, middle of the crest width, and middle of the side slope). In contrast, three earth pressure cells (E1, E3, and E5) were installed in reinforced section G1 on the top of piles, while three earth pressure cells (E2, E4, and E6) were placed on the surface of their corresponding surrounding soils. These sensors with a diameter of $120 \mathrm{~mm}$ have a high spatial resolution of $0.1 \mathrm{kPa}$ and a measuring range of $0 \sim 2 \mathrm{MPa}$. Field monitoring was conducted three times per week during the filling stage and once per week during the placement stage. Its total duration is over 1000 days. Note that not all the data points were presented in the figures shown in the upcoming sections for the sake of conciseness.

\section{Results and Discussion}

3.1. Ground Surface Settlements. Figure 5 presents the variation of ground surface settlements and fill heights with elapsed time for test sections. The embankment construction approximately follows three stages as indicated by I, II, and III, corresponding to the main filling, placement, and ballast construction. The percentages of the total settlement occurred at these three stages (each stage including filling and placement stages) are summarized in Table 1. Regardless of unreinforced and reinforced embankments, the settlements follow similar patterns. As shown in Figure 5(b) and Table 1, the dominant settlements occurred during the embankment filling stages, and smaller settlements were observed during the placement stages. This indicates a quick primary consolidation process followed by a very limited secondary consolidation. The settlements are stabilized during 3 months after the end of embankment construction. After that, a small increment in settlement took place due to the ballast construction. These responses highlight that the soil foundation is more likely to deform under drained conditions during the slow embankment filling process (in the reinforced section, about 35 days and 45 days to raise $3.5 \mathrm{~m}$ and $4.2 \mathrm{~m}$, resp.) despite the low permeability of the natural CDG soils varying from $5.20 \times 10^{-9}$ to $5.44 \times 10^{-8} \mathrm{~m} / \mathrm{s}$.

It can be clearly seen from Table 1 that the percentages of the total settlement occurred during secondary and third (postconstruction) periods for the reinforced section are far lower than those of the unreinforced section. It can be concluded that the performance of the reinforced embankment on accelerating the long-term settlements is better than that of the

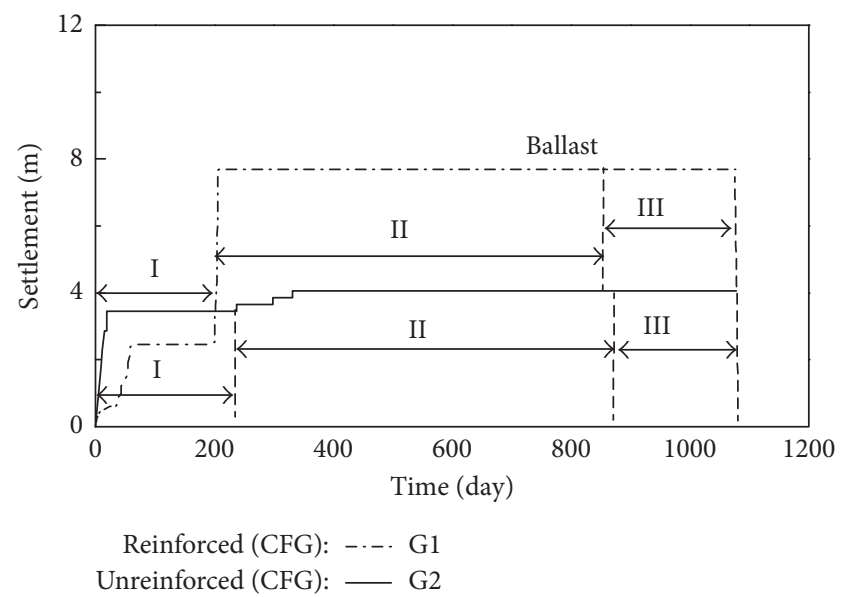

(a)

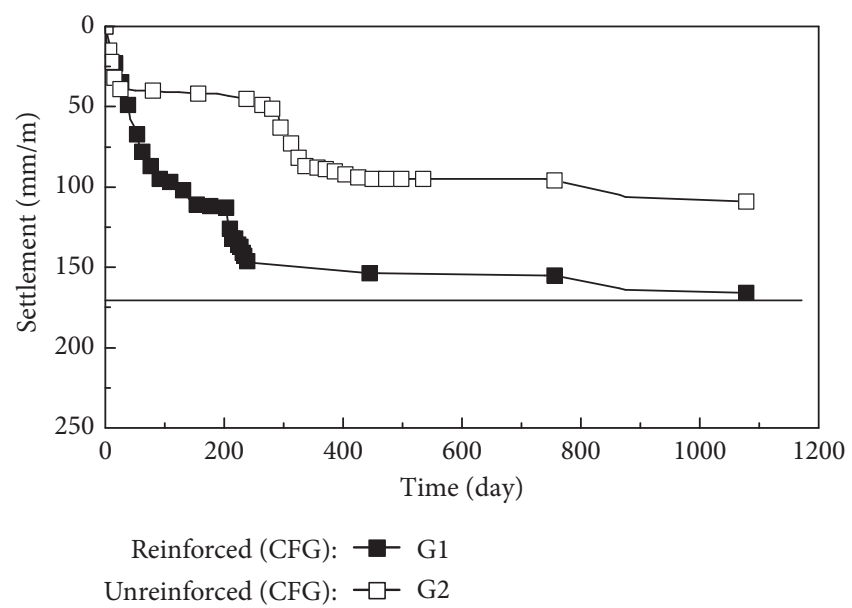

(b)

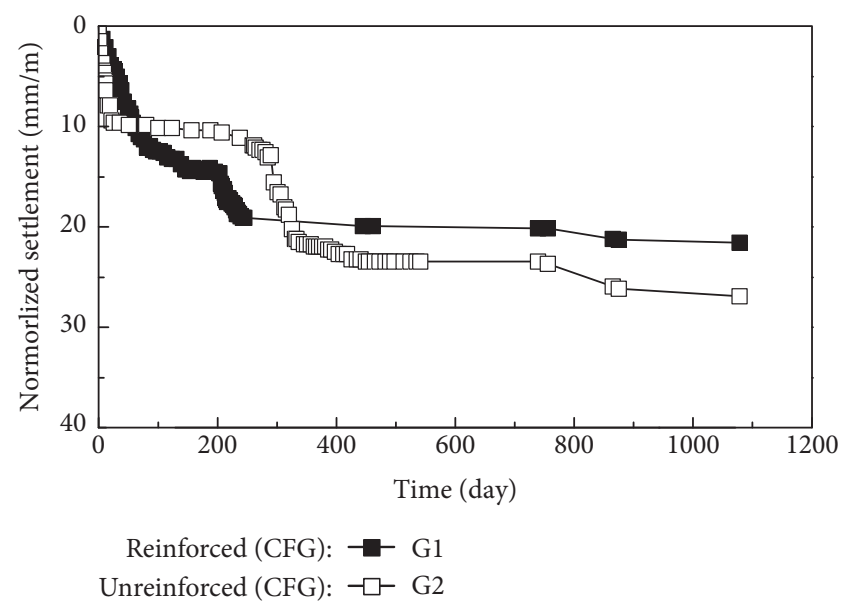

(c)

FIgURE 5: Variation of fill heights (a), ground surface settlements (b), and ground surface settlements normalized by fill heights (c) with elapsed time for test embankment sections.

unreinforced embankment. Furthermore, the percentage of the total settlement occurred at the first period for reinforced section is significantly higher than that of the unreinforced embankment due to the acceleration of the settlement process. 
TABLE 1: Proportion of the total settlement for test embankments.

\begin{tabular}{|c|c|c|c|c|c|c|}
\hline \multirow{2}{*}{ Section } & \multirow{2}{*}{ Improvement method } & \multirow{2}{*}{ Filling stage } & \multirow{2}{*}{ Duration (day) } & \multicolumn{3}{|c|}{ Proportion of the total settlement (\%) } \\
\hline & & & & Filling stage & Placement stage & Total \\
\hline \multirow{3}{*}{ G1 } & \multirow{3}{*}{ Reinforced (CFG) } & I & 201 & 44.6 & 23.5 & 68.1 \\
\hline & & II & 658 & 6.0 & 24.7 & 30.7 \\
\hline & & III & 219 & - & 1.2 & 1.2 \\
\hline \multirow{3}{*}{ G2 } & \multirow{3}{*}{ Unreinforced } & I & 237 & 29.4 & 11.9 & 41.3 \\
\hline & & II & 628 & 37.6 & 17.4 & 55.0 \\
\hline & & III & 213 & - & 3.7 & 3.7 \\
\hline
\end{tabular}

Note. The postconstruction settlements occur at stage III.

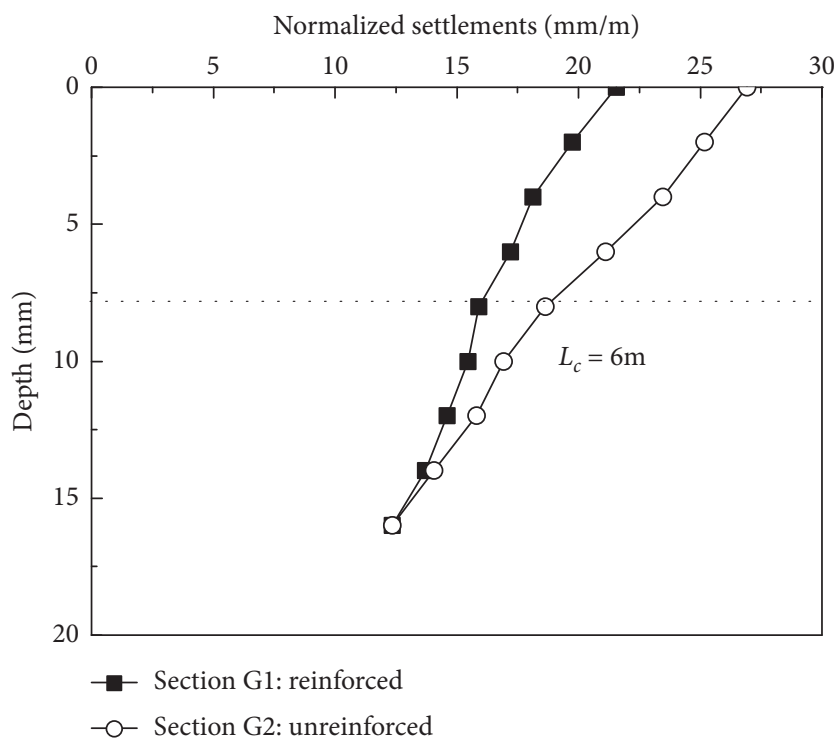

FIgURE 6: Profiles of settlements normalized by embankment heights at different depths for test embankment sections.

TABLe 2: Proportion of the layer settlement for test embankments.

\begin{tabular}{lccc}
\hline \multirow{2}{*}{ Section } & Improvement method & \multicolumn{3}{c}{ Proportion of the layer settlement (\%) } \\
& & Reinforced soil layer (at a depth of 0-6 m) & Subsoil beneath piles (below the depth of $6 \mathrm{~m}$ ) \\
\hline G1 & Reinforced & 20.2 & 79.8 \\
G2 & Unreinforced & 21.6 & 78.4 \\
\hline
\end{tabular}

This means that compared with the unreinforced embankment, the settlement of the reinforced embankment can be easier to be compensated during the main embankment filling stage (stage I). For the purpose of comparison, the ground settlements normalized by fill heights are also shown in Figure 5(c). We can conclude that the CFG pile-supported embankment has good performance on reducing the total settlement in short and long terms, well satisfying the requirements in vertical settlements for high-speed railways [6].

3.2. Layer Settlements. The layer settlements in soils are determined by the differential settlements obtained by the adjacent magnetic loops. Figure 6 shows the layer settlement profiles. The settlements are normalized by the maximum embankment heights at different depths for the reinforced and unreinforced embankments. It can be seen from Figure
6 that, at the depth of $0-17 \mathrm{~m}$ from the ground surface, the normalized layer settlements of the reinforced embankment are significantly lower than those of the unreinforced embankment. Note that the convergence depths $\left(L_{c}\right)$ are $6 \mathrm{~m}$ equivalent to the pile length. Table 2 shows that the compression of reinforcement (at a depth of $0-6 \mathrm{~m}$ ) is nearly four times larger than that of the subsoil (below the depth of $6 \mathrm{~m}$ ) underlain by the reinforcement. However, the compression of the reinforcement is slightly lower than that of the unreinforced soil layer in the counterpart. This means that smaller deformation occurs at the shallow soils of the reinforced embankment and results in the development of embankment stability.

3.3. Load Transfer Analysis Based on Earth Pressure Measurements. The consistency of all earth pressure 


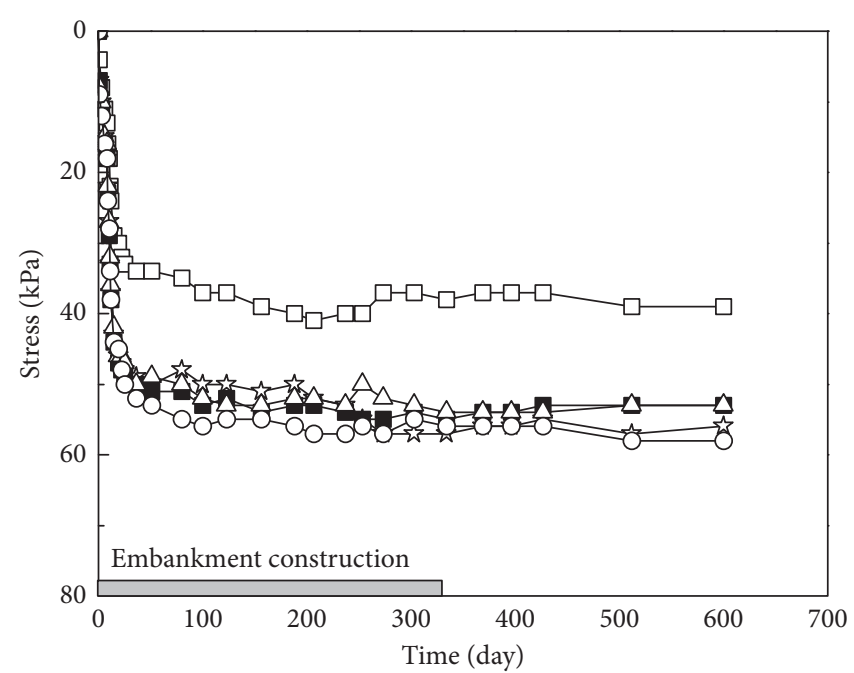

Unreinforced G2:

$\begin{array}{ll}\square-\mathrm{F} 1 & -\checkmark \mathrm{F} 4 \\ \rightarrow-\mathrm{F} 2 & -\mathrm{F} 5 \\ \rightarrow \text { F3 } & \end{array}$

(a)

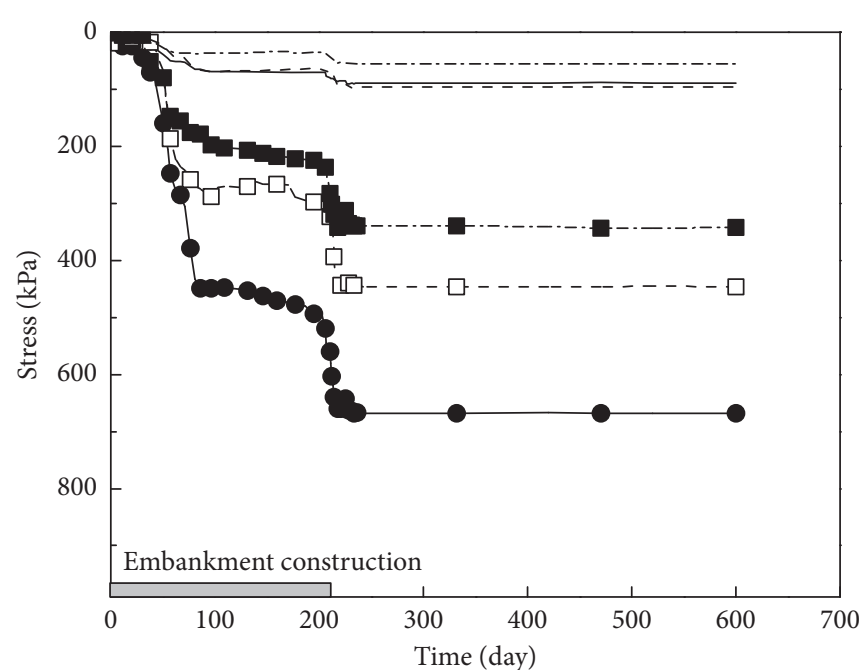

Unreinforced G1:

$\begin{array}{ll}\longrightarrow-\mathrm{E} 1 & -- \text { E4 } \\ -\mathrm{E} 2 & --\mathrm{E} 5 \\ -\square-\mathrm{E} 3 & --\cdot \text { E6 }\end{array}$

(b)

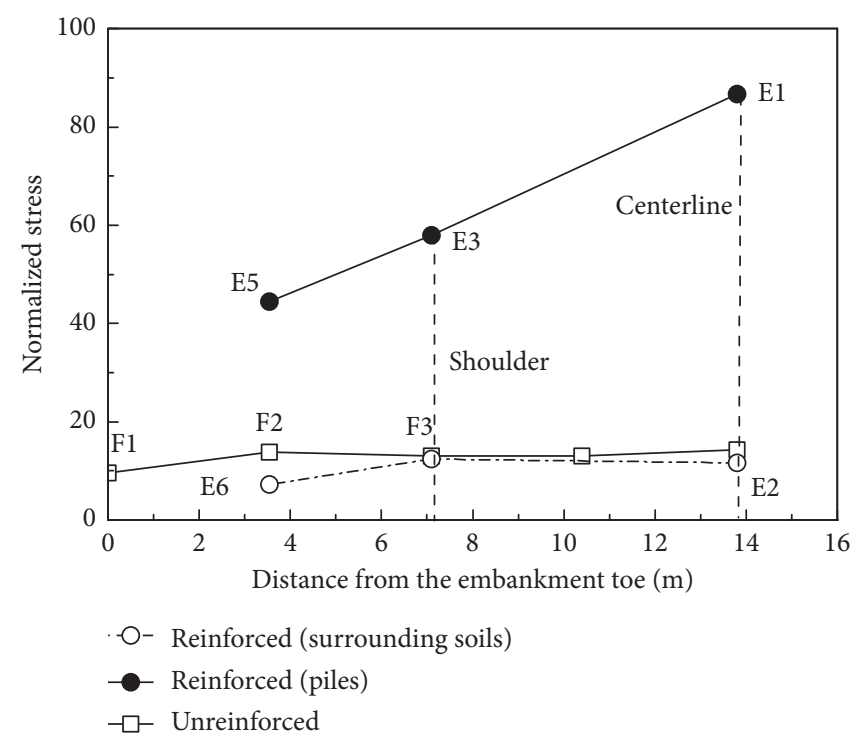

(c)

FiguRE 7: Temporal variation of earth pressure with elapsed time for unreinforced (a) and reinforced (b) embankments and normalized stress along the distance from the embankment toe (c).

measurements for reinforced and unreinforced embankments is illustrated in Figures 7(a) and 7(b). First observation is that the evolution pattern of all earth pressures follows the process of embankment construction. For instance, the earth pressures mainly increase during the filling stages, whereas a very small change appears during the placement stages. Further comparison shows that the earth pressures measured on the top of pile caps are significantly higher than those measured on the surface of surrounding soils. This highlights that there is an important soil arching effect developed at both the centerlines and shoulder lines of test embankments. In Figure $7(\mathrm{c})$, the earth pressures normalized by the embankment heights show that the stresses measured on the surrounding soils for reinforced embankments are lower than those of unreinforced embankments. It means that a significant stress reduction on the soils was observed in the reinforced section in comparison to the unreinforced embankment. For the reinforced embankment, the stresses measured at the pile heads are much higher than those applied to the surrounding soils. The final stress concentration at the centerline is 7.5 , and the load transfer occurs during the embankment construction. 


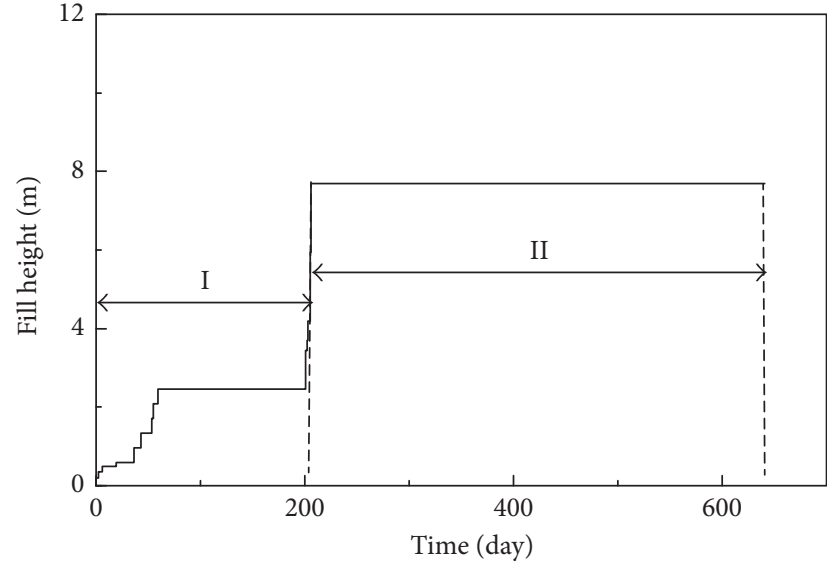

— Reinforced (CFG) G1

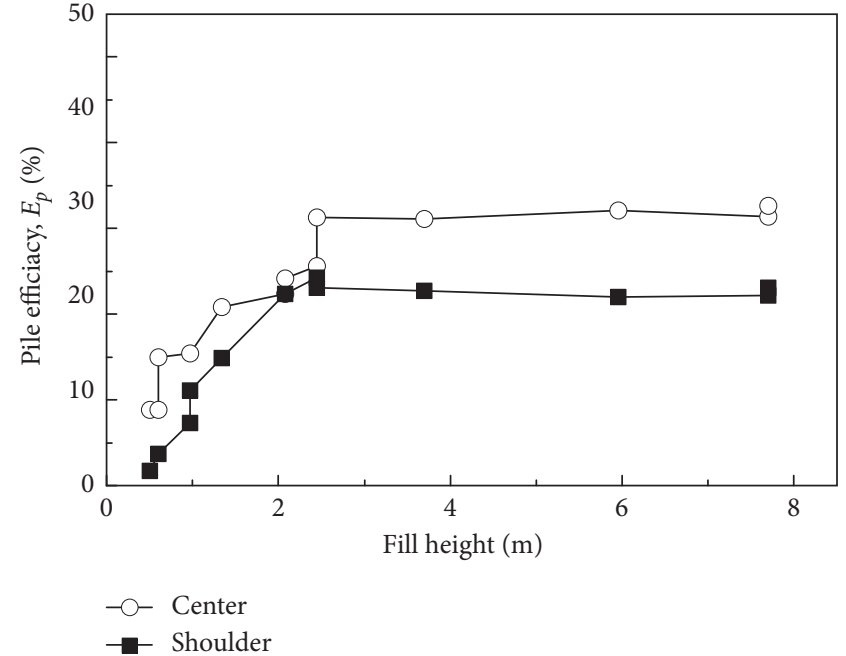

(b)

Figure 8: Variation of fill height with time (a) and pile efficacy with embankment fills (b).

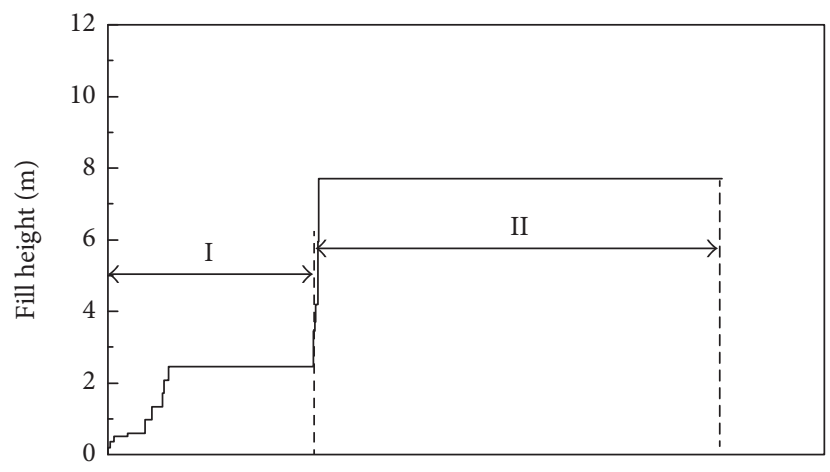

— Reinforced G1

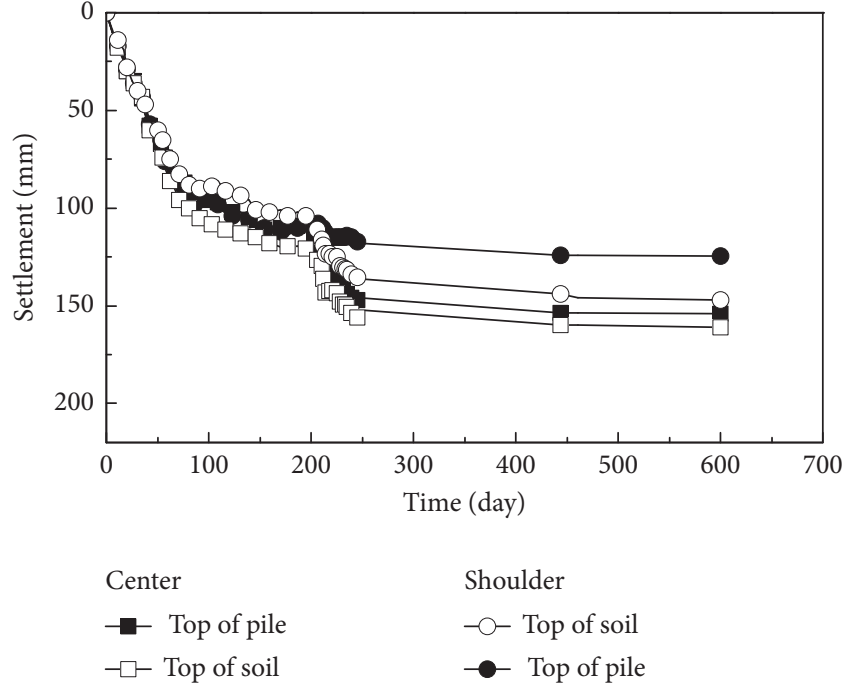

(b)

(a)

FIGURE 9: Temporal variation of fill height (a) and settlements (b) at the top of pile caps and the surrounding soils with time in the reinforced section.

The load transfer mechanism through the soil arching effect can be further investigated through the pile efficacy $E_{p}$, which is defined as a proportion of the total embankment load carried by the piles:

$$
E_{p}=\frac{\sigma_{p} A_{p}}{\sigma_{p} A_{p}+\sigma_{s} A_{s}}
$$

where $\sigma_{p}$ and $\sigma_{s}$ are the average stress on the pile and on the soil, respectively; $A_{p}$ is the area of pile; $A_{s}$ is that of the soil between piles (tributary area).

Pile efficacy is plotted against the fill height as presented in Figure $8(\mathrm{~b})$. We can clearly see that the pile efficacy is raised in a dramatic manner for the fill height below $2.5 \mathrm{~m}$, beyond which it slightly increases. In other words, with the embankment filling, the load supported by the surrounding soils is progressively transferred to the piles due to the development of differential settlements between piles and their surrounding soils (Figure 9).

Figures 8 and 7(b) show that significant increases in pile efficacy and stress on the top of piles occur during the placement of stage I when the height of the embankment is less than $2.5 \mathrm{~m}$, while those for embankments over $2.5 \mathrm{~m}$ in height remained unchanged during the placement of stage II. More than $68 \%$ of the total settlement occurs during stage I. This indicates that the subsoil deformation in the reinforced section caused by soil consolidation results in more arching during the soil consolidation phase. However, the increase of soil arching for the CFG pile-supported embankment is more significant than that measured in the experiments for the CM pile-supported embankment [5]. This is because less 
TABLE 3: Summary of approaches of different design methods for the aching effect.

\begin{tabular}{|c|c|c|c|c|c|}
\hline Design method & Main parameter & Arching geometry & Subsoil support & Equation of critical height & Critical height $(\mathrm{m})$ \\
\hline BS8006 & $s, d, C_{c}, \gamma$ & 3D-SSA & No & $1.4(s-d)$ & 1.82 \\
\hline Modified BS8006 & $s, d, C_{c}, \gamma$ & 3D-SSA & No & $1.4(s-d)$ & 1.82 \\
\hline Nordic method & $s, d, \alpha_{0}, \gamma$ & 3D-SSA & No & $1.2(s-d)$ & 1.56 \\
\hline CA model & $s, d, K_{p}, \gamma, k, \varphi_{k}^{\prime}$ & 2D-SSA & Ground reaction module & $s_{d} / 2$ & 1.27 \\
\hline EBGEO [23] & $s, d, K_{g}, K_{p}, k, \gamma, \varphi_{k}^{\prime}$ & 2D-SSA & Ground reaction module & $s / 2$ & 0.9 \\
\hline
\end{tabular}

Note. $s$ is the pile spacing $(1.8 \mathrm{~m}) ; s_{d}$ is the diagnose pile spacing $(2.55 \mathrm{~m}) ; d$ is the pile diameter $(0.5 \mathrm{~m}) ; C_{c}$ is the arching coefficient; $\gamma$ is the unit weight of the fill material $\left(19 \mathrm{kN} / \mathrm{m}^{3}\right) ; \alpha_{0}$ is the angle of load diffusion in geosynthetic reinforcement and fill for the Nordic method; $K_{g}$ is the tensile stiffness of the geogrid $(1600 \mathrm{kN} / \mathrm{m}) ; k$ is the ground reaction modulus; $\varphi_{k}^{\prime}$ is the fill material internal friction angle ( 35 degrees); SSA is the semispherical arch; $K_{p}$ is the passive earth pressure coefficient.

differential settlements between piles and soils were observed in the experiments on CM pile-supported embankments. Therefore, soil arching is mainly influenced by differential settlements between surrounding soils and piles other than the soil deformation solely caused by soil consolidation.

It should be noted that a total of $32.6 \%$ and $23.1 \%$ of the upper load at the embankment centerline and shoulder line are supported by the piles, as shown in Figure 8. It is significantly lower than that of the CM pile-supported embankment built over CDG soils [5]. The latter is varying from $42 \%$ to $48 \%$. The large pile spacing of the CFG pilesupported embankment can explain the low pile efficacy. However, in this case, the measured stress concentration at the embankment centerline is 7.5 for the piled embankment without pile caps. It proves that the soil arching is fully effective, even if the pile spacing is large.

3.4. Verification of Design Standards and Approaches. The current designing methods of BS8006 [17], German EBGEO [18], and Nordic method [19] are adapted widely by engineers to calculate the pile efficacy. Meanwhile, van Eekelen [20] proposed a modified version of BS8006 by correcting the significant mistakes in BS8006, which is a reference to calculate the equally distributed vertical loads on the reinforcement strips repeatedly. To enhance the prediction accuracy of pile efficacy for pile-supported embankments, an advanced method named "three-dimensional concentric arches model (CA model)" was presented by van Eekelen et al. [14, 21].

Nordic method, BS8006, and its modified version do not take into account the subsoil support, leading to the overestimation of the loads on the reinforcement strip. Compared with the three methods discussed earlier, German EBGEO considers the subsoil support partly but neglects the impact of subsoil consolidation by means of ground reaction and fill angle. The concentric arches model (CA model) is an extension of the EBGEO method. For the load deflection behavior, the CA model method replaces uniform and triangular load distribution in German EBGEO [18] and Zaeske [22] with inverse triangular load distribution. Table 3 presents the summary of approaches of different methods for the arching effect. In this paper, depending on the field motoring data, pile efficacy calculated by the five methods mentioned above is used to verify the applicability of these methods to the CFG pilesupported embankment built over CDG soils.

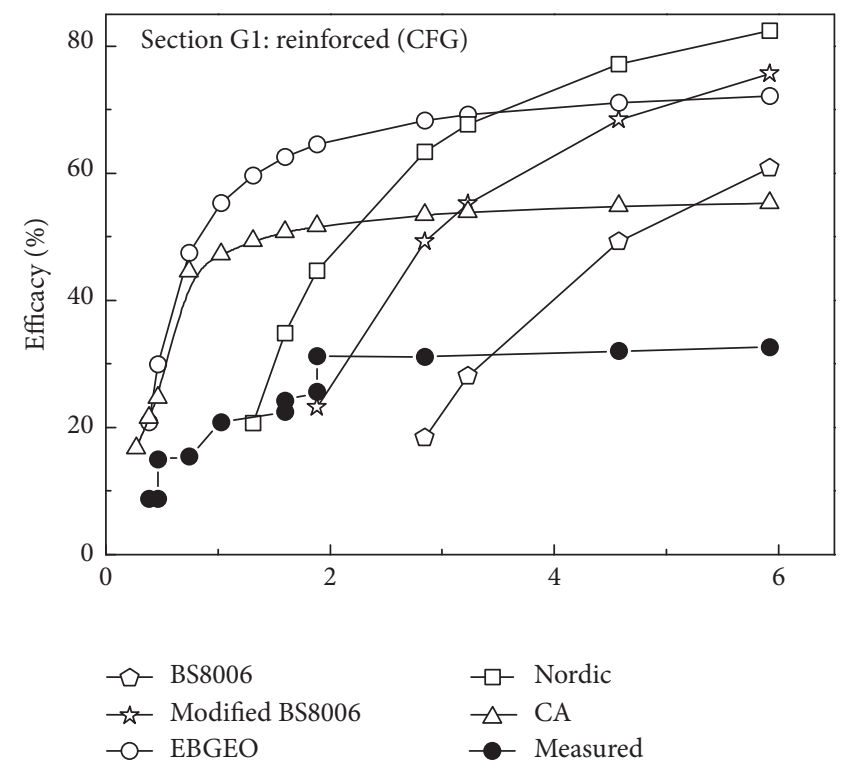

FIGURE 10: Comparison of pile efficiency and measured values with the normalized embankment height for the CFG pile-supported embankment.

Figure 10 presents a comparison of pile efficacy beneath the geogrid layers calculated by different designing methods and measured values obtained from the full-scale experiment. The material parameters used in calculating are as follows: pile length $L=6 \mathrm{~m}$, pile diameter $d=0.5 \mathrm{~m}$, pile spacing $s=1.8 \mathrm{~m}$, unit weight $\gamma=19 \mathrm{kN} / \mathrm{m}^{3}$, and ground reaction modulus $k=1600 \mathrm{kN} / \mathrm{m}$. It can be seen from Figure 10 that all methods overpredict the pile efficacy of the CFG pile-supported embankment in comparison to the measured values, leading a conservative design (i.e., safe). Moreover, the overestimation by the Nordic method, BS8006, and its modified version significantly increases with the embankment height. This is because these three methods do not take into account the effect of subsoil support and overestimate the vertical stress applied on the piles.

In Figure 10, pile efficacy calculated by the EBGEO and CA model method shows that it generally levels off once full arches $(H>0.9 \mathrm{~m}$ for EBGEO and $H>1.27 \mathrm{~m}$ for CA model method) are formed. It means that the effect of soil consolidation on the pile efficacy seems to be not significant in case of formation of full arches. Therefore, the pile efficacy 
patterns calculated by the EBGEO and CA model method match the experimental results better in comparison to the calculation by the Nordic method, BS8006, and its modified version. Furthermore, the calculation by the CA model method is in accordance with the experimental results in both the pattern and measured value at the end of construction. Thus, the CA method is recommended to predict the pile efficacy in this case.

\section{Conclusion}

This paper presents a set of full-scale experiment data for the embankments built over CDG soils reinforced by geogrid only and by geogrid and CFG piles. The comparison of measured values between the unreinforced embankment and piled embankment shows that the CFG pile-supported embankment accelerates the soil consolidation and settlement stabilization. The settlements obtained from the full experiment well satisfy the settlement allowance. In general, the CFG pile-supported embankment performs well on the CDG soils.

One important point that emerges from the full-scale experiments is a significant increase in soil arching caused by soil consolidation. The increase of soil arching (pile efficacy) is heavily dependent on differential settlements between surrounding soils and piles other than soil deformation solely caused by consolidation. However, high measured stress concentration of 7.5 indicates that the soil arching is fully effective.

The effect of surrounding soil support on soil arching could not be neglected in the case of stiff pile-supported embankments (i.e., CFG piles) built over low-strength soils. The experimental results verified the applicability of the five methods to estimate the pile efficacy of the CFG pilesupported embankment built over CDG soils. The calculation results show that the Nordic method, BS8006, and its modified version yield a significant overestimation of pile efficacy, whereas the calculation by the EBGEO and CA model method matches the measured values better. The calculation of pile efficacy by the EBGEO and CA model generally follows the same pattern, which is also verified by the experimental results. By contrast, the pile efficacy predicted by the CA method is significantly closer agreement with the measured values.

\section{Appendix}

\section{Calculation Method for Pile Efficacy}

(i) BS8006 [6]: for $0.7(s-d)<H<1.4(s-d)$, the partial arching occurred, and the pile efficiency can be calculated by

$$
\begin{aligned}
E_{p} & =1-\frac{2(s-a)}{s} \chi, \\
\chi & =\frac{s^{2}-d^{2}\left(p_{c}^{\prime} /(\gamma H+p)\right)}{s^{2}-d^{2}} .
\end{aligned}
$$

For $H>1.4(s-d)$, the full arching occurred, and the pile efficiency can be calculated by

$$
E_{p}=1-\frac{2.8 \gamma(s-d)^{2}}{s(\gamma H+p)} \chi
$$

where $H$ is the embankment height; $s$ is the centerto-center pile spacing; $\gamma$ is the unit weight of the embankment fill; $d$ is the pile diameter; $p$ is the surcharge on the top of the fill; $p_{c}^{\prime}$ is the load part transferred directly to the pile cap, $p_{c}^{\prime} / \sigma_{v}^{\prime}=\left(C_{c} d / \mathrm{H}\right)^{2}$; $\sigma_{v}^{\prime}$ is the average applied vertical effective stress; $C_{c}$ is the arching coefficient.

(ii) Modified BS8006 [19]:

Partial arching:

$$
E_{p}=1-\frac{\left(s^{2}-d^{2}\right) \chi}{s^{2}} .
$$

Full arching:

$$
E_{p}=1-\frac{1.4 \gamma(s-d)\left(s^{2}-d^{2}\right)}{s(\gamma H+p)} \chi .
$$

(iii) German EBGEO [17]:

$$
\begin{aligned}
E_{p}= & 1-\frac{\sigma_{v, r}\left(s^{2}-0.25 \pi d^{2}\right)}{\gamma H s^{2}}, \\
\sigma_{v, r}= & \lambda_{1}^{x} \cdot\left(\gamma+\frac{q_{0}}{h}\right) \cdot\left(H \cdot\left(\lambda_{1}+\frac{H_{c}^{2} \cdot \lambda_{2}}{4}\right)^{-x}\right. \\
& \left.-H_{c}\left(\left(\lambda_{1}+\frac{H_{c}^{2} \lambda_{2}}{4}\right)^{-x}-\left(\lambda_{1}+H_{c}^{2} \cdot \lambda_{2}\right)^{-x}\right)\right), \\
x= & \frac{d\left(K_{p}-1\right)}{\lambda_{2} \cdot s}, \\
K_{p}= & \tan ^{2}\left(45^{\circ}+\frac{\varphi_{k}^{\prime}}{2}\right), \\
\lambda_{1}= & \frac{1}{8}(s-d)^{2}, \\
\lambda_{2}= & \frac{s^{2}+2 d s-d^{2}}{2 \cdot s^{2}},
\end{aligned}
$$

where $\sigma_{v, r}$ is the average vertical stress on the reinforcement strip; $H_{c}$ is the critical height, $H_{c}=s / 2$ for $H \geq s / 2, H_{c}=H$ for $H<s / 2 ; K_{p}$ is the coefficient of passive earth pressure, $K_{p}=1+$ $\sin \varphi / 1-\sin \varphi$.

(iv) Nordic Hand [18] suggested that the load carried by geosynthetic reinforcement is calculated by a wedge with a top angle of $30^{\circ}$. Pile efficiency can be calculated as follows: 


$$
\begin{aligned}
E_{p} & =1-\frac{W_{3 \mathrm{DT}}^{\prime}}{\gamma H s^{2}} \\
W_{3 \mathrm{DT}}^{\prime} & =0.93 \frac{1+s / d}{2}(s-d)^{2} \gamma,
\end{aligned}
$$

where $W_{3 \mathrm{DT}}^{\prime}$ is the weight of the wedge of the threedimensional model.

(v) The CA model [20] assume the soil arching as a hemisphere. The area and volume of the crown element are calculated in two or three dimensions as follows:

$$
\begin{aligned}
& E_{p}= 1-\frac{\sigma_{r, 2 D}}{\gamma H s^{2}}, \\
& \sigma_{r, 2 D}=\left(\frac{2}{s}\right)^{\left(K_{p}-1\right)}\left[\gamma H+p-\frac{s \gamma\left(K_{p}-1\right)}{2\left(K_{p}-2\right)}\right] \gamma\left(K_{p}-1\right) \\
&+\frac{\gamma}{K_{p}-2} \gamma .
\end{aligned}
$$

\section{Notations}

$E_{p}: \quad$ Pile efficacy (\%)

OCR: Overconsolidation ratio

$H$ : Embankment height (m)

$H_{c}$ : Critical height $(\mathrm{m})$

$s: \quad$ Pile spacing $(\mathrm{m})$

$s_{d}: \quad$ Diagnose pile spacing $(\mathrm{m})$

$d: \quad$ Pile diameter $(\mathrm{m})$

$R: \quad$ Pile radius $(\mathrm{m})$

$\gamma$ : Unit weight of embankment filling $\left(\mathrm{kN} / \mathrm{m}^{3}\right)$

$A_{p}: \quad$ Area of the pile $\left(\mathrm{m}^{2}\right)$

$A_{s}$ : $\quad$ Area of the soil between piles $\left(\mathrm{m}^{2}\right)$

$W_{T}$ : Distributed vertical load acting on the reinforcement between adjacent pile caps $(\mathrm{kPa})$

$W_{3 \mathrm{DT}}^{\prime}$ : Weight of the wedge in three dimensions $(\mathrm{kN})$

$p_{c}^{\prime}$ : $\quad$ Load part transferred directly to the pile cap $(\mathrm{kPa})$

$q$ : $\quad$ Surcharge on the embankment $(\mathrm{kN})$

$\sigma_{v}^{\prime}: \quad$ Average applied vertical effective stress $(\mathrm{kPa})$

$\sigma_{v, r}: \quad$ Average pressure applied on the reinforcement $(\mathrm{kN})$

$\sigma_{r, 2 \mathrm{D}}$ : Radial stress in two dimensions applied on the reinforcement $(\mathrm{m})$

$f_{\mathrm{fs}}$ : $\quad$ Partial coefficient for soil load

$f_{q}: \quad$ Partial coefficient for surcharge load

$C_{c}: \quad$ Arching coefficient

$K_{p}$ : Coefficient of passive earth pressure

$K_{g}: \quad$ Tensile stiffness of the geogrid $(\mathrm{kN} / \mathrm{m})$

$k$ : $\quad$ Ground reaction modulus $\left(\mathrm{kN} / \mathrm{m}^{3}\right)$

$\varphi k^{\prime}$ : Friction angle of embankment filling (degree)

$S: \quad$ Settlement of soil foundation $(\mathrm{mm})$

$\alpha_{0}$ : $\quad$ Angle of load diffusion for the Nordic method (degree)

$\chi: \quad$ Constant used by the EBGEO

$\lambda_{1}, \lambda_{2}$ : Constants used by the EBGEO

$\nu$ : $\quad$ Poisson's ratio.

\section{Conflicts of Interest}

The authors declare that there are no conflicts of interest.

\section{Acknowledgments}

The financial support from the funding of the Technological Research and Development Programs of the Ministry of Railways (no. 2010G003-F) and the Chinese Scholarship Council within the China state-funded visiting academic Overseas Research Programme is greatly appreciated.

\section{References}

[1] L. Briançon and B. Simon, "Pile-supported embankment over soft soil for South Europe Atlantic high speed line," Geosynthetic International, vol. 24, no. 3, pp. 293-305, 2017.

[2] L. Briançon and B. Simon, "Performance of pile-supported embankment over soft soil: full-scale experiment," Journal of Geotechnical and Geoenvironmental Engineering, vol. 138, no. 4, pp. 551-561, 2012.

[3] R. P. Chen, Z. Z. Xu, Y. M. Chen, D. S. Ling, and B. Zhu, "Field tests on pile-supported embankments over soft ground," Journal of Geotechnical and Geoenvironmental Engineering, vol. 136, no. 6, pp. 777-785, 2010.

[4] M. A. Nunez, L. Briançon, and D. Dias, "Analyses of a pilesupported embankment over soft clay: full-scale experiment, analytical and numerical approaches," Engineering Geology, vol. 153, pp. 53-67, 2013.

[5] L. J. Wu, G. L. Jiang, X. F. Liu, H. B. Xiao, and D. C. Sheng, "Performance of geogrid-reinforced pile-supported embankments over decomposed granite soil," in Proceedings of the Institution of Civil Engineers-Geotechnical Engineering, 2017.

[6] Code TB10621-2009, Code for Design of High-Speed Railway, Ministry of Railways of the People's Republic of China, Beijing, China, 2009, in Chinese.

[7] T. G. Ham, Y. Nakata, R. P. Orense, and M. Hyodo, "Influence of gravel on the compression characteristics of decomposed granite soil," Journal of Geotechnical and Geoenvironmental Engineering, vol. 136, no. 11, pp. 1574-1577, 2010.

[8] M. Hossain and J. Yin, "Behavior of a compacted completely decomposed granite soil from suction controlled direct shear tests," Journal of Geotechnical and Geoenvironmental Engineering, vol. 136, no. 1, pp. 189-198, 2009.

[9] W. M. Yan and X. S. Li, "Mechanical response of a mediumfine-grained decomposed granite in Hong Kong," Engineering Geology, vol. 129-130, pp. 1-8, 2012.

[10] M. Blanc, G. Rault, L. Thorel, and M. Almeida, "Centrifuge investigation of load transfer mechanisms in a granular mattress above a rigid inclusions network," Geotextiles and Geomembranes, vol. 36, pp. 92-105, 2013.

[11] H. Xing, Z. Zhang, H. Liu, and H. Wei, "Large-scale tests of pile-supported earth platform with and without geogrid," Geotextiles and Geomembranes, vol. 42, no. 6, pp. 586-598, 2014.

[12] Y. I. Oh and E. C. Shin, "Reinforcement and arching effect of geogrid-reinforced and pile-supported embankment on marine soft ground," Marine Georesources \& Geotechnology, vol. 25, no. 2, pp. 97-118, 2007.

[13] J. T. Shahu and Y. R. Reddy, "Estimating long-term settlement of floating stone column groups," Canadian Geotechnical Journal, vol. 51, no. 7, pp. 770-781, 2014.

[14] S. J. M. van Eekelen, A. Bezuijen, and A. F. van Tol, "Validation of analytical models for the design of basal reinforced 
piled embankments," Geotextiles and Geomembranes, vol. 43, no. 1, pp. 56-81, 2015.

[15] Code JGJ/T87-2012, Technical Specification for Engineering Geological Prospecting and Sampling of Constructions, Ministry of Housing and Urban-rural Development of the People's Republic of China, Beijing, China, 2012, in Chinese.

[16] ASTM (2011) D 2487-11, Standard Practice for Classification of Soils for Engineering Purposes, ASTM International, West Conshohocken, PA, USA, 2011.

[17] BS 8006-1, Code of Practice for Strengthened/Reinforced Soils and Other Fills, BSI, London, UK, 2010.

[18] EBGEO (Empfehlungen für Bewehrungen aus Geokunststoffen), Recommendations for Design and Analysis of Earth Structures using Geosynthetic Reinforcements-EBGEO, Ernst \& Sohn (Wiley), Berlin, Germany, 2010.

[19] Y. Rogbeck, C. Alén, and G. Franzén, Nordic Guideilnes for Reinforced Soils and Fills, Nordic Geotechnical Societies, Stockholm, Sweden, 2002.

[20] S. J. M. van Eekelen, A. Bezuijen, and A. F. van Tol, "Analysis and modification of the British Standard BS8006 for the design of piled embankments," Geotext. Geomembranes, vol. 29, no. 3, pp. 345-359, 2011.

[21] S. J. M. Van Eekelen, A. Bezuijen, and A. F. Van Tol, "An analytical model for arching in piled embankments," Geotext. Geomembranes, vol. 39, pp. 78-102, 2013.

[22] D. Zaeske, Zur Wirkungsweise von unbewehrten und bewehrten mineralischen Tragschichten über pfahlartigen Gründungselementen, Schriftenreihe Geotechnik, Uni Kassel, Heft, vol. 10, 2001, in German.

[23] H. G. Kempfert, G. Gobel, D. Gobel, and C. Heitz, "German recommendations for reinforced embankments on pilesimilar elements," in Proceedings of EuroGeo3-Third European Geosynthetics Conference, Geotechnical Engineering with Geosynthetics, pp. 279-284, Munich, Germany, March 2004. 


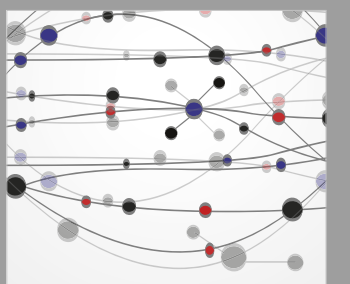

The Scientific World Journal
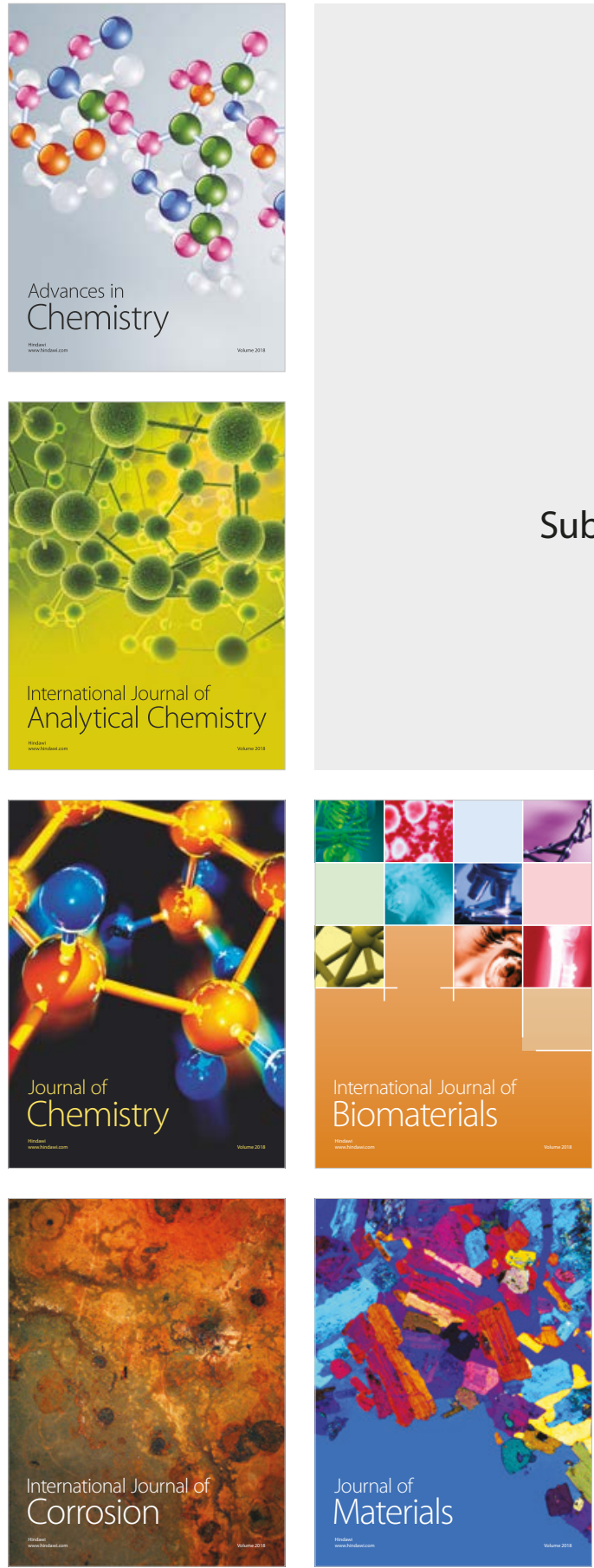

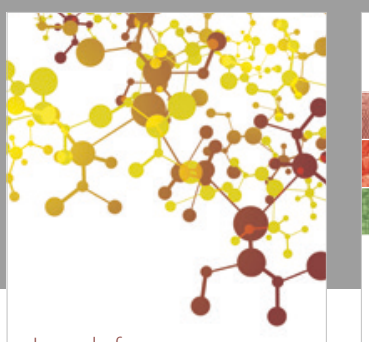

Journal of

Applied Chemistry
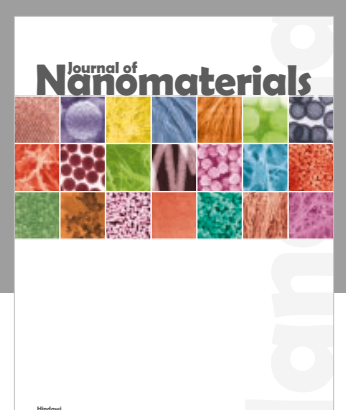

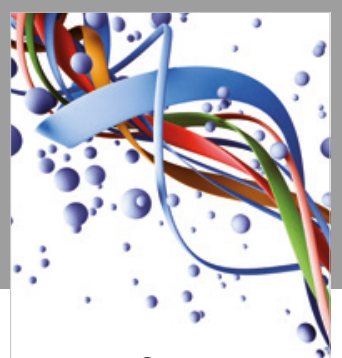

Scientifica

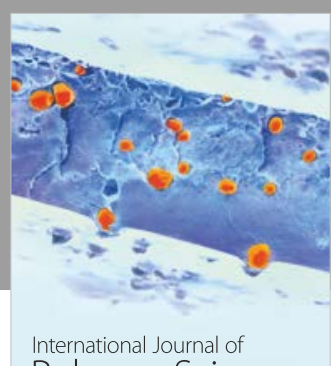

Polymer Science

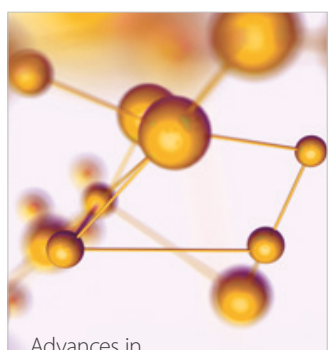

Physical Chemistry
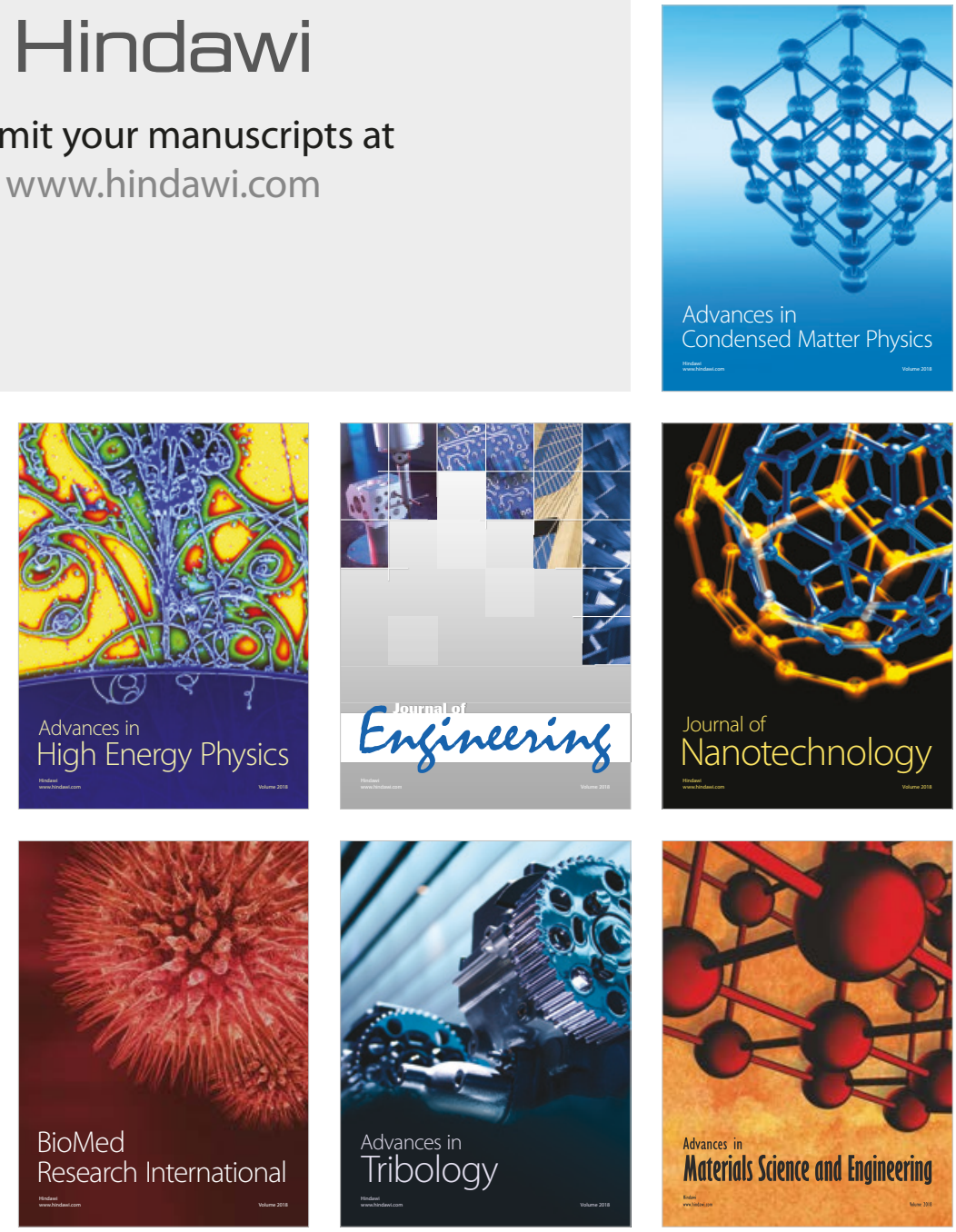